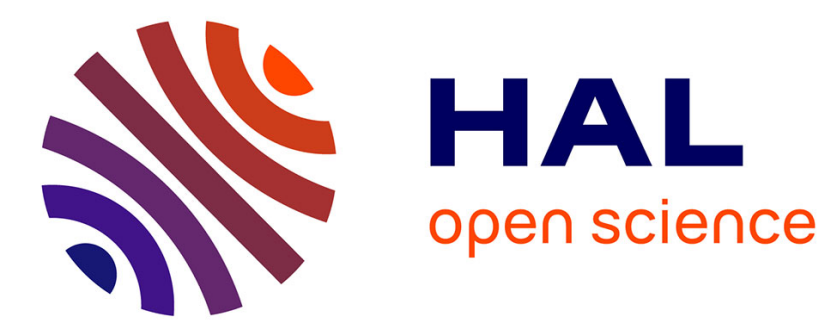

\title{
University affiliated Think Tanks in Armenia
}

Vardan Atoyan

\section{To cite this version:}

Vardan Atoyan. University affiliated Think Tanks in Armenia. Austrian Journal of Humanities and Social Sciences, 2015, 11-12, pp.58-59. hal-03271676v2

\section{HAL Id: hal-03271676 \\ https://hal.science/hal-03271676v2}

Submitted on 21 Sep 2021

HAL is a multi-disciplinary open access archive for the deposit and dissemination of scientific research documents, whether they are published or not. The documents may come from teaching and research institutions in France or abroad, or from public or private research centers.
L'archive ouverte pluridisciplinaire HAL, est destinée au dépôt et à la diffusion de documents scientifiques de niveau recherche, publiés ou non, émanant des établissements d'enseignement et de recherche français ou étrangers, des laboratoires publics ou privés. 


\title{
Section 5. Political science
}

\author{
Atoyan Vardan, \\ Director of National Security Research Program \\ AMBERD Research Center, \\ Armenian State University of Economics, PhD \\ E-mail:vardanatoyan@yahoo.com ; atoyan.amberd@asue.am
}

\section{University affiliated Think Tanks in Armenia}

\begin{abstract}
The Article describes current positioning of think tanks in Armenian universities and gives general information. Existing issues and improvement opportunities are discussed.
\end{abstract}

Key words: Think Tanks, University Science, Armenia.

\section{Introduction}

In the context of political, economic, civilization and variety of other challenges of the $21^{\text {st }}$ century all spheres of modern society are transformed. In current situation to meet challenges facing the state and society, sustainable development, implementation of national security and elaboration of efficient governing mechanisms a great deal goes to organizations implementing intellectual product such as research and analytical centers based in universities and academic environment.

University think thanks are often considered as more equitable and their researches are more objective as the latter compared to other centers of strongly oriented ideological or political point according to their traditions and systems are under control of academic society $[1,110]$.

Think thanks are influential players of current democratic society, as important as international, public and business sphere organizations $[2,71]$.

\section{Challenges and opportunities}

It should be noted that this important role is still not accomplished clearly and completely regarding the social sciences sphere in Armenia. Its necessity taking into account some exceptions is not revaluated enough. Research of university think thanks gives us opportunity to assume that in general university research is not on a strong ground sufficiently. Research and teaching at universities are mainly separated and function independently from each other. University education first and foremost is considered a system reproducing current knowledge and science where elaboration of new knowledge is not a priority. Maybe this is the reason that though some universities implement researches in the frames of separate projects or groups but considering the institutional point either there are no permanent functioning centers or are not developed well.

On the other hand relations between science-policyeconomy-society are rather weak. One of the reasons is that according to the formed behavior humanities and social sciences are framed in some research communities (research institutes, non-governmental organizations and universities). Though some humanities research centers of Armenian universities have experience in cooperation with foreign organizations that is mainly carried in the frames of joint researches, expert exchanges, publication founding and organization of conferences. Mainly there is no interuniversity cooperation between local university research centers $[3,79]$.

Despite it may be considered positive that currently the viewpoint of Soviet times has been gradually shifting with the idea that Armenian universities are mainly education implementing institutes and research and scientific studies should be implemented by the academic and research institutes mainly. By the support of the Government and efforts of the university leaders though very slowly some steps are taken, mechanisms and tools are elaborated that give opportunity to foster and promote scientific and research activities. Evidence of the above mentioned is the concept towards development of humanities and social sciences in the sphere of social sciences to improve specialized level of researches and meeting current demand of the society elaborated by the State Science Committee and submitted to the Government of the Republic of Armenia. The concept was elaborated according to the points of "Strategy of Science sphere development" approved by the protocol decree of the Government of the Republic of Armenia dated 27 May, 2010.

It is necessary to mention that number of research centers based in Armenian universities has sustainable growth dynamics. Currently 29 research centers of humanities are based in 17 state and 24 non-state universities of Armenia. Yerevan State University is obviously the leader of the sphere and has 15 analytical centers, American University of Armenia has 4 centers, Public Administration Academy of the Republic of Armenia- 3, Yerevan Brusov State University of Languages and Social Sciences - 2, University "Urartu" of Phycology and Sociology - 2, Armenian State University of Econom- 
ics - 1, Russian- Armenian Slavonic University - 1, Goris State University -1 .

According to research area the mentioned conditionally can be classified according to the following types: Armenian studies ( 2 centers), Cultural and civilization ( 6 centers), Economic ( 2 centers), Sociological (4 centers), Psychological ( 7 centers), Environmental-health ( 3 centers), InformationStrategic ( 3 centers), Scientific and Educational ( 2 centers).

Research of activities of humanities-analytical centers based in Armenian universities emphasizes that the mentioned centers partly coincide with accepted international standards from the point of view of their development tendencies and existing resources though this is not comprehensive outline how the think thank should consider all its standards. Besides difference of think thank activities and research in general of state and non-state universities rather varies which is also very distressing. The latter are mainly satisfied with implemented functions of research and scientific group which is of more administrative, organizational and coordination nature and often are limited by organizing annual conferences.

The next issue refers the ties: low integration level between different centers, weak ties in research level, cooperation between experts, remarks on ongoing political and economic changes and joint efforts to finding ways of meeting the challenges. Considering that the universities have key role not only in the knowledge accumulation, exchange and dissemination process but also elaboration of new knowledge and its application. One of their key issues is to feel and why not foresee changes and trends in the country, outline possible ways of development, and last but not least provide beneficiaries with intellectual product by highly qualified researches and advice.

In the context of the above mentioned it should be mentioned that modern think thanks implement a very important social function: from one hand their output is scientific and intellectual and from the other hand they play a very significant political role reflecting different sides of social and political thought and becoming bridge between the academic science and applied policy. At the same time development stream of the sphere shows that think tanks gradually take one of the main components of the political system of any country. Those not only elaborate current foreign policy, considering methods of meeting symmetric and asymmetric threats but also try to foresee the future. Trying to foresee the future and possible scenarios of developments, being ready for the consequences we try to change and somehow edify it $[4,63]$.

\section{Conclusion}

Concluding it should be emphasized that Armenian university based think tanks distinctively differ from each other both from structural point of view and activity transparency. Think tanks based in some universities do not have web-sites, accounts in social network; information in some web sites is not updated permanently or is incomplete.

Nevertheless comprehensive efforts towards the improvement of the sphere within previous years have given some optimism and it may be expected that in case of such permanent trends positive changes in the nearest future will be more tangible.

\section{References:}

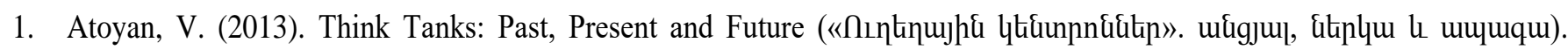
Messenger of ASUE, 1 (29), 104-117. Available at SSRN: https://ssrn.com/abstract=3856674

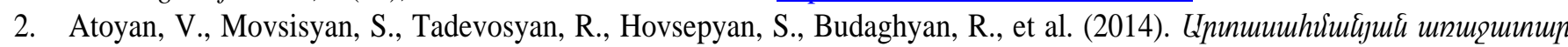

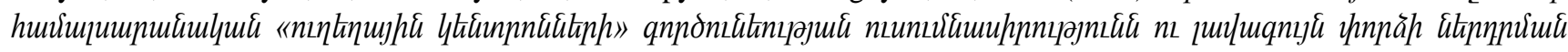

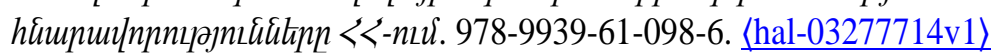

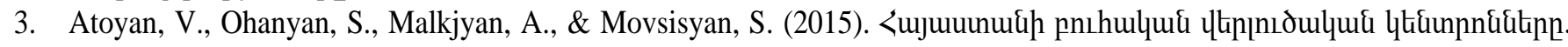
978-9939-61-120-4. 〈hal-03278141)

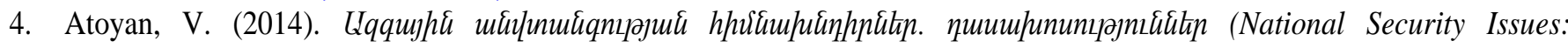
Lectures). National Security Issues (Lectures), Yerevan, Tntesaget. Available at SSRN: https://ssrn.com/abstract=3856656 